\title{
The Effect of Robusta (Coffea canephora var. Robusta) Coffee Brew on Pulmonary Histopathological Changes in Male Wistar Strain White Rats (Rattus norvegicus)
}

\author{
Dian Yuliartha Lestari ${ }^{a}$, Meddy Setiawan ${ }^{b}$, Lukman Baihaqi $^{c}$. \\ a.Department of Pathology, ${ }^{b}$ Department of Internal Medicine, ${ }^{\mathrm{c}}$.Medical Student \\ Muhammadiyah Malang University \\ Malang, Indonesia \\ dianyuliarthalestari@gmail.com
}

\begin{abstract}
The acrylamide content in coffee is formed during roasting process. Acrylamide is a carcinogenic substance which allows the occurrence of lung tumors in mice. Acrylamide causes mutations of EGFR and KRAS proto-oncogenes that increase the risk of lung tumors. Objective: This study aimed to prove the effect of robusta (Coffea canephora var. Robusta) coffee brew on pulmonary histopathological changes in male Wistar strain white rats (Rattus norvegicus). This study used a true experimental posttest only control group design. We devided 24 samples of rats into 6 groups; Negative K1, Positive K2 which was given acrylamide, K3, K4, K5 and K6 which were given brewed coffee in a dose of $0.36 \mathrm{ml} / 200 \mathrm{gBW}, 0.72 \mathrm{ml} / 200 \mathrm{gBW}, 1.44 \mathrm{ml} / 200$ gBW, and $2.16 \mathrm{ml} / 200 \mathrm{gBW}$ respectively. We used One-Way ANOVA, Post Hoc Tukey, Correlation and Regression statistical test method to analyze the data. One-Way ANOVA showed sig. $0.000(P<0.05)$ means a significant effect. Tukey test showed sig. $(P<0.05)$ with K4, K5, K6 differ significantly to negative K1 whereas K3 did not differ significantly to negative K1. Pearson correlation test values obtained was 0.882 . The strength of the brewed coffee affects $77.7 \%$ of normal bronchial epithelial cell hyperplasia. Hyperplasia in this study was occurred because the content of acrylamide in coffee caused mutations of EGFR and KRAS proto-oncogenes. Robusta (Coffea canephora var. Robusta) coffee brew can cause changes in histopathological picture of pulmonary bronchial epithelial cell from male Wistar strain white rats (Rattus norvegicus, Wistar strain)
\end{abstract}

Keywords-Robusta coffee brew; acrylamide; bronchial epithelial cell; hyperplasia; mutation of the gene.

\section{INTRODUCTION}

Coffee is one of the most widely consumed beverages. Coffee consumption in Indonesia has average increase of 3\% annually, higher than the growth of average worldwide coffee consumption of about $2 \%$ [1].

In general, coffee has two main kinds, arabica and robusta coffee. However, Robusta coffee production (93\%) is much larger than Arabica coffee (7\%). Since Robusta coffee is more desirable than the Arabica coffee due to its better taste and better crops quality than Arabica [1].
The content of caffeine, cafestol, melanoidin, saponins, phenolic compounds and chlorogenic acid in coffee has a good effect on human health, such as lowering the risk of type 2 diabetes mellitus, cardiovascular risk, and uric acid; improve memory; improve neurotransmitter system $[2,3,4]$.

Coffee also have unfavorable effects which is acrylamide. Acrylamide is formed when we roast the coffee at high temperatures $\left(>120^{\circ} \mathrm{C}\right)$ [5]. Acrylamide has been classified as a substance that can cause cancer or a potential human carcinogen [6]. The International Agency for Research on Cancer (IARC) said that acrylamide is a substance shown to cause cancer in experimental animals but has not been established to cause cancer in humans [5]

Acrylamide, a carcinogenic substance, contained in coffee goes into the body of experimental animals and can cause gene mutations. The mutations are mutations of EGFR followed by KRAS proto-oncogenes mutations, since both genes were located on the same locus. Mutations that can happen are proto-oncogene mutations in K-ras which can cause lung adenocarcinoma [6].

\section{RESEARCH METHODS}

This study used true experimental with posttest only control group design. This study used Wistar strain rats aged 10-12 weeks, weighing 150-200 grams, divided into 6 groups: 1 negative control group, 1 positive control group, and 4 groups with different coffee dose $(0.36 \mathrm{ml}, 0.72 \mathrm{ml} ; 1.44 \mathrm{ml}$, $2.16 \mathrm{ml}$ ) for 28 days. We obserbed the mice off the presence or absence of epithelial cell hyperplasia of the bronchus characterized by an increased number of epithelial cells. 


\section{RESULTS}

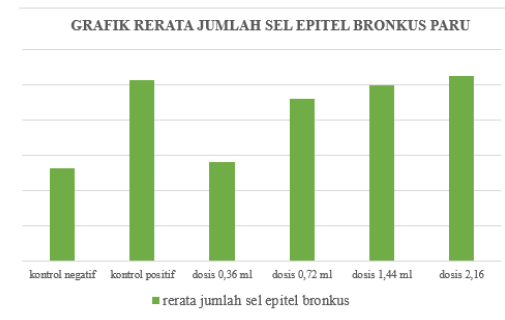

Fig. 1. Average Count of Bronchial Epithelial Cell. (Primary data, 2016)

The graph above showed the average count of epithelial cells per treatment group. Negative control group bronchial epithelial cells count was 524.50, the first treatment group with brewed coffee dose of $0.36 \mathrm{ml} / 200 \mathrm{~g}$ of body weight rats bronchial epithelial cells count was 565.25, the second treatment group cell count with $0.72 \mathrm{ml}$ dose was 918.25 , the third treatment group cell count with a dose of $1.44 \mathrm{ml}$ was 996.00, and the final treatment group cell count with a dose of $2.16 \mathrm{ml}$ was 1049.00 .

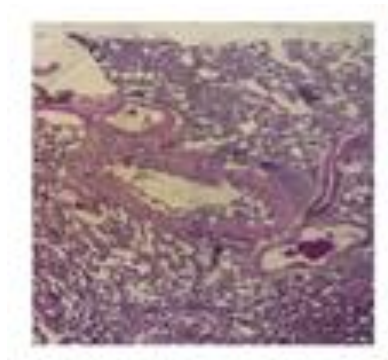

a

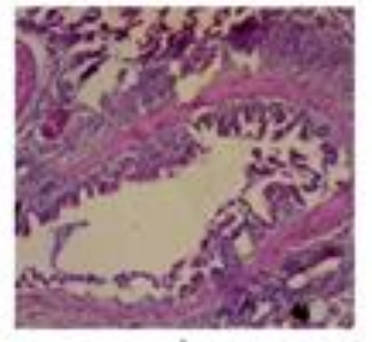

b

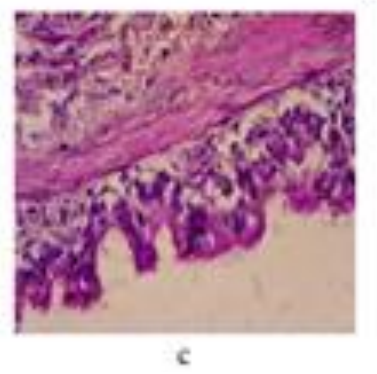

Fig. 2. Microscopic View of the Lung with Robusta Coffee Brew: Bronchial Epithelial Cell Hyperplasia. (a) 40x magnification, (b) 100x magnification, (c) 400x magnification.

\section{IV.DISCUSSION}

This study proved that there were differences in the cell count of bronchial epithelial cell male Wistar strain rats (Rattus norvegicus Wistar strain) between the negative control group to the treatment group. When the dosage of brewed coffee was increased, the cell count of bronchial epithelial cells will also increased. In the group of male Wistar strain rats that were given dose of $2.16 \mathrm{ml} / 200 \mathrm{gBW}$ robusta coffee brew the highest cell count result was found compared to the other dose treatment which was 1049.00. This was influenced by the level of acrylamide contained in a brewed coffee, the greater the coffee dose given, the greater the level of acrylamide. This was consistent with previous studies conducted by Yahdiana Harahap in 2006, which said that eating foods with high heating will form acrylamide substance that can increase the likelihood of the risk of lung tumors in mice, starting with the stage adaptation of cell hyperplasia.

According to the theory of carcinogenesis, cell adaptation is in the initiation phase, which only shows increased cell proliferation, and no visible histological and biochemical changes [8]. It was also shown in this study, as from the histology preparation reading we did not find any changes in histology except increased proliferation (hyperplasia) of bronchial epithelial cells in male Wistar strain white rats which were given robusta coffee brew contained carcinogenic substances (acrylamide) for 28 days.

In this study, exposure to 28 days had resulted in bronchial epithelial cell hyperplasia; this was confirmed by a study from Elna Kartawiguna in 2001 which said that the time needed from the first cells attacked by carcinogens to form a lesion in genetic material is only in a few minutes.

From Pearson correlation test, we obtained positive value $(0.882)$ in the correlation coefficient and indicated that the robusta coffee brew dosage and the amount of bronchial epithelial cell count is directly proportional. It meant that the greater the dose of robusta coffee brew given, the greater the increase of bronchial epithelial cell count. It proved that there is a very strong relationship between the given dosage of robusta coffee brew and bronchial epithelial cell hyperplasia of white rats.

Based on the regression test results, this study showed that the effect of robusta coffee brew dosage to the increase in bronchial epithelial cells of white rats lung was $77.7 \%$, which meant that $77.7 \%$ of the bronchial epithelial cells count increase was influenced by robusta coffee brew and the remaining $22.3 \%$ can be influenced by other factors, either endogenous or exogenous factors that were not examined in this study.

Endogenous factors were the one affecting metabolic imbalance, hormonal imbalance, immune system and cell cycle abnormalities. Exogenous factor were the one affecting robusta coffee brew given to the animals. Coffee was one of antioxidants main sources in people's daily diet. The healthy effects of coffee were usually associated with high antioxidant activity (ability to inhibit the oxidation process). Many publications provided a comparison of antioxidant activity in beverages such as coffee, tea, and cocoa. The antioxidant activity of coffee was associated with chlorogenic, ferulic, caffeic, and n-coumaric acid contained in it [9].

This indicated that the coffee used in this study has two compounds that work the opposite, which were carcinogenic substances and antioxidants. It can be a confounding factor in this study, because it was still unknown about how the content of carcinogenic substances in this study was more dominant than antioxidants in the coffee used. 


\section{CONCLUSION}

Robusta (Coffea canephora var. Robusta) coffee brew has histopathologic affect on bronchial epithelial cell count in male Wistar strain rats (Rattus norvegicus Wistar strain) in the form of cell hyperplasia.

\section{REFERENCES}

[1] Kemenperin (Kementrian Perindustrian), Roadmap Industri Pengolahan Kopi, 2009, (downloaded on 1 Februari 2016), from http://agro.kemenperin.go.id.

[2] D. Ganmaa, W.C. Willett, T.Y. Li, D. Feskanich, R.M. van Dam, E. Lopez-Garcia, D.J. Hunter, et al., "Coffee, tea, caffein and rial of breast cancer: A 22-year follow up," International Journal of Cancer, vol. 122, no. 9, pp. 2071-6, 2008.

[3] H.K. Choi, G. Curhan, "Coffea, tea and caffeine consumption and serum Uric Acid level: The Third National Health and nutrition examination survey," Arthritis Care \& Research, 57:5, Pp. 816-821, 2007.

[4] E. Mostofsky, G. Schlaug, K.J. Mukamal, W.D. Rosamond, M.A. Mittleman "Coffee and Acute Ischemic Stroke Onset: The Stroke and Onset Study,” Neurology, Vol. 75, No. 18, pp 1583-8, 2010.

[5] Y. Harahap, "Pembuatan Akrilamida Dalam Makanan dan Analisisnya," Makalah Ilmu Kefarmasian, 11th ed., Vol. III No. 3, pp. 107-116, 2006, (downloaded on 20 Februari 2015), from http://staff.ui.ac.id/system/files/users/yahdiana.ms/material/akrilamid.p df.

[6] M. Friedman, "Chemistry, Biochemistry, and Safety of Acrylamide. A Review," J. Agric. Food. Chem, 51, Pp. 4504-4526, 2003.

[7] J.D. Minna, "Neoplasms of The Lung," 16th ed., USA: McGraw-Hill Med Pub, 2005. [Ed Principles of Internal Medicine]

[8] E. Kartawiguna, "Faktor-Faktor yang Berperan pada Karsinogenesis," Jurnal Kedokteran Trisakti, Vol.20, No.1 Januari-April 2001, Pp. 1618, 2001.

[9] Y Alexander, Y Yakov, YW Jing, N. Boris, "Antioxidant and Antiradical Activity of Coffee," Journal of Antioxidants [Online], Vol. 2, pp. 230-242, 2013 (downloaded on February 9, 2015), from www.mdpi.com/journal/antioxidants. 